\title{
HEALTH PRACTITIONER REGULATION IN AUSTRALIA: A VIEW FROM THE ANTIPODES
}

Regulação das profissões de saúde na Austrália: uma visão de antípodas

${ }^{1}$ University of Sydney. Sydney, Australia.

Correspondence: cameron.stewart@sydney.edu.au

Received: 11/22/2018. Approved: 03/11/2019. 


\section{ABSTRACT}

This article reviews health practitioner regulation in Australia. It starts with a review of the constitutional powers to regulate healthcare in the Australian Federal system and the system of rights to access health that have been created. The article then examines the current National Law, which was an attempt to create a uniform regulatory system for healthcare practitioners in Australia. The paper examines the working of that system and current data on its operation and concludes with looking to future challenges for the system.

\section{Keywords:}

Australia; Australian Access to Health System; Health Workforce Regulation.

\section{RESUMO}

Este artigo analisa a regulação dos profissionais de saúde na Austrália. Começa descrevendo os poderes constitucionais para regular os serviços de saúde na federação australiana e o sistema criado de direitos de acesso à saúde. O artigo examina a atual Lei Nacional de Regulação do Profissional de Saúde, que tenta criar um sistema regulatório uniforme para os profissionais de saúde na Austrália. O trabalho investiga o funcionamento desse sistema e os dados atuais sobre sua operação, concluindo com um olhar sobre seus desafios futuros.

\section{Palavras-chave:}

Austrália; Acesso ao Sistema de Saúde Australiano; Regulação das Profissões de Saúde. 


\section{Introduction}

Australia has, in recent times, made enormous changes to the structure of its health workforce regulation. In 2009 the Australian Federal government and the various State and Territory governments created the National Registration and Accreditation Scheme (NRAS), which was Australia's first attempt at creating a nation-wide system of health workforce regulation. The NRAS created a framework of laws referred to as the Australian Health Practitioner Regulation National $\mathbf{L a w}^{1}$ (National Law) to implement the scheme which each State and Territory implemented with the co-operation of nine (later 14, and now 15) different health professions. The system regulation accreditation, registration and professional discipline. The system has been described as 'polycentric' given it involves nine different governments, 15 professions, eight health care complaints bodies and nine different tribunal systems ${ }^{2}$.

This article begins by giving a basic outline of the Australian polity and its constitutional arrangements. It then proceeds to look at the specific constitutional arrangements for the delivery of healthcare and the division of responsibility between the Australian Federal government and the Australian States and Territories. The article then examines the National Law, an attempt at creating a uniform system of registration and professional discipline for healthcare in Australia. The article examines the structures of the regulation, the systems of complaints and notifications, the disciplinary processes, and the regulation of unregistered health practitioners, bringing together the latest data on the National Law's activities. The article concludes with some thoughts on future directions for the National Law.

\section{A short outline of the Australian legal system}

Australia is a constitutional monarchy made up of a federation of six former British colonies: New South Wales, Queensland, South Australia, Tasmania, Victoria and Western Australia. It has a total population of 25 million people, with most of the population living on the eastern coastal fringe 3 . The original colony, New South Wales, was established by the British Crown on 26 January 1788, and the other colonies were established over the next century. The Commonwealth of Australia, a federated body made up of the six colonies, was formed in 1901, after peaceful

\footnotetext{
${ }^{1}$ QUEENSLAND GOVERNMENT. Health Practitioner Regulation National Law Act 2009. Reprint current from 1 December 2018 to date. Available at: <https://www.legislation.qld.gov.au/view/html/inforce/current/act2009-045>. Accessed in: 28 March 2019.

2BENNETT, Belinda, CARNEY, Terry, CHIARELLAI, Mary, WALTON, Merrilyn, KELLY, Patrick, SATCHELL Claudette, BEAUPERT, Fleur. Australia's national registration and accreditation scheme for health practitioners: a national approach to polycentric regulation? Sydney Law Review, v.40, n. 2, p. 140-181, 2018.

${ }^{3}$ AUSTRALIAN BUREAU OF STATISTICS. Australian demographic statistics. Mar 2018. Available at: <http:// www.abs.gov.au/AUSSTATS/abs@.nsf/mf/3101.0>. Accessed in: 10 Nov. 2018.
} 
devolution of power from the Imperial British parliament ${ }^{4}$. New South Wales is the largest state in terms of population with 7.5 million residents, four million of which live in its capital city, Sydney ${ }^{5}$.

The British Crown retained supremacy over Australia but all vestiges of the power of the Imperial parliament to change Australian law were finally removed in $1986^{6}$. The holder of the British Crown also holds the Crowns of Australia and all of its States. The royal functions of the Crown are given to vice-regal appointments, namely Governors for the States and a Governor General for the Federal parliament. These vice-regal appointments are not democratically elected but are appointed by the British monarch on advice from the head of the respective governments ${ }^{7}$.

All of Australia's States and its Federal system employ a Westminster-model bicameral ('two housed') legislature, apart from Queensland which has one legislative house. The executive arm of government is not separate from the legislature in the Westminster system and Australian governments employ a British Cabinet-style of executive.

Power is shared between the Federal government and the States under the Commonwealth of Australia Constitution Act 1901 (Cth) (Australian Constitution). Specific powers are granted to the Federal government ${ }^{8}$. Some exclusive power is given to the Federal government (such as defence and currency) but the vast majority of powers granted to it are concurrent powers, also shared by the States. If there is conflict between a valid Federal law and State law, the Federal law is superior to the extent of the inconsistency'.

In addition to the States of Australia, there are two significant Territories, which have self-government: the Australian Capital Territory and the Northern Territory. These Territories have their own legislatures but they are subject to the power of the Federal government, which can override Territory legislation on any matter ${ }^{10}$.

\footnotetext{
${ }^{4}$ Australian Constitution Act 1901 (UK). Available at: <https://www.aph.gov.au/About_Parliament/Senate/ Powers_practice_n_procedures/Constitution.aspx>. Accessed in: 29 Mar. 2019.

${ }^{5}$ AUSTRALIAN BUREAU OF STATISTICS. Quick stats for Greater Sydney. Available at: <http://quickstats. censusdata.abs.gov.au/census_services/getproduct/census/2016/quickstat/1GSYD?opendocument>. Accessed in: 10 Nov. 2018.

${ }^{6}$ Australia Act 1986 (Cth); Australia Act 1986 (UK). Available at <https://www.foundingdocs.gov.au/itemsdid-103.html>. Accessed in: 29 Mar. 2019.

${ }^{7}$ Australian Constitution, s 51, cit.

${ }^{8}$ WILLIAMS, George, BRENNAN, Paul., LYNCH, Andrew. Australian constitutional law: commentary and materials. $7^{\text {th }}$ ed. Sydney: Federation Press, 2018.

${ }^{9}$ Australian Constitution, s 109 , cit.

${ }^{10}$ Australian Constitution, s 122, cit.
} 


\section{Australian common law and the position of Australian Aboriginals and Torres Strait Islanders}

Notionally, there is one common law for Australia, which is based on the English law as adapted for Australian conditions, over the last 230 years ${ }^{11}$. Unlike the North American States, Australian States and Territories do not have individual common laws, and Australian courts apply a theory of a unified Australian common law. However, as the States and Territories have their own power to legislate, differences in laws have emerged over time.

Legally, it has been said that English common law was brought to Australia on 26 January $1788^{12}$. This was due to the application of the doctrine of reception, a common law doctrine which states that when land is unoccupied, settlers will apply their own laws to the colony, as far as it is practicable to do so ${ }^{13}$. Because Australia was treated as having been peaceably settled, English law was therefore established, and sovereignty was recognised in the British Crown.

Importantly, Australian Aboriginals and Torres Strait Islanders have been in occupation of the territory now known as Australia for tens of thousands of years. Neither the former British colonies nor the Federal government have ever entered into a binding treaty with Aboriginal Australians or Torres Strait Islanders. As such there is no recognition of the former sovereignty of indigenous Australians ${ }^{14}$. Given the failure of the legal systems to recognise the sovereignty of indigenous Australians, no war was ever declared against them and the continent is treated by law as having been peaceably settled (even though this is substantially at odds with facts) ${ }^{15}$. While there was originally recognition, by the courts of New South Wales, of Aboriginal laws and land rights ${ }^{16}$, this later gave way to the fiction that New South Wales (and the rest of Australia) was a 'terra nullius', effectively a 'no man's land'17. In 1992, the High Court rejected the concept of terra nullius, and recognised that Aboriginal land rights could survive, but only when they had not been extinguished by British powers, colonial authorities, and later, Australian governments ('the Mabo case') ${ }^{18}$. The Mabo case did not recognise the sovereignty of indigenous Australians, only the possibility that they had property rights in land. Indigenous Australians are

\footnotetext{
${ }^{11}$ STEWART, Cameron, KERRIDGE, Ian, PARKER, Malcolm. The Australian medicolegal handbook. Sydney: Elsevier 2008.

${ }^{12}$ Australian Courts Act 1828 (UK). Available at: <https://www.foundingdocs.gov.au/item-did-39.html>. Accessed in: 29 Mar. 2019.

${ }^{13}$ CREYKE, Robyn; HAMER, David; O'MARA, Patrick; SMITH, Belinda; Taylor, T. Laying down the law. $10^{\text {th }}$ ed. Sydney: LexisNexis 2017.

${ }^{14}$ Id. Ibid.

${ }^{15}$ Id, Ibid.

${ }^{16} R$ v Bonjon [1841] NSWSupC 92.

${ }^{17}$ KERCHER, Bruce. R v Ballard, R v Murrell and R v Bonjon. Australian Indigenous Law Reporter v. 3, n 3, p. 410, 1998.

${ }^{18}$ Mabo v The State of Queensland (1992) 175 CLR 1
} 
therefore subject to the ordinary laws of Australia and have no right to their own legal systems, unless such rights are granted by the States and Territories.

\section{The constitutional power to regulate healthcare}

Importantly, the Australian Federal government does not enjoy a general power over health but there are some constitutional powers enumerated, such as quarantine powers, which indirectly affect healthcare ${ }^{19}$. After World War II attempts were made by the Federal government to create a system of pharmaceutical benefits which would provide free medicines to poorer Australians, but the efforts were found to be unconstitutional given the lack of power in the Constitution ${ }^{20}$. In response, the Constitution was later amended to include a power to regulate social welfare insurance including "pharmaceutical, sickness and hospital benefits, medical and dental services (but not so as to authorize any form of civil conscription)"21. The wording forbids the nationalisation of healthcare, but it has allowed for Federal funding of health activities and programs and, as the financial power of the Federal government has grown, the Federal government's practical power to regulate healthcare has expanded.

Today the Federal government's main roles in regulating health are as follows:

(i) the regulation of the introduction of therapeutic goods and drugs via the Therapeutic Goods Administration (TGA). The TGA's role is to assess the safety and efficacy of health products ${ }^{22}$;

(ii) the provision of subsidised drugs via the Pharmaceutical Benefits Scheme (PBS). Drugs which are approved to be listed by the Pharmaceutical Benefits Advisory Council, can be obtained at much reduced rates, and are available to some classes of patients free of $\cos ^{23}$;

(iii) the provision of advice funding for health and medical research through the National Health and Medical Research Council (NHMRC); and

(iv) the provision of funding for advice regarding safety and quality in the health service provision through the Australian Commission on Safety and Quality in Health Care (Commission), jointly funded by Federal and State governments

\footnotetext{
${ }^{19}$ Australian Constitution, s 51(ix), cit.

${ }^{20}$ Attorney-General (Vic); Ex rel Dale v Commonwealth (1945) 71 CLR 237.

${ }^{21}$ Australian Constitution, s 51(xxiiiA), cit

${ }^{22}$ Therapeutic Goods Act 1989 (Cth). See also AUSTRALIAN THERAPEUTIC GOODS ADMINISTRATION. Regulation basics. Available at: <https://www.tga.gov.au/regulation-basics>. Accessed in: 10 Nov. 2018.

${ }^{23}$ National Health Act 1953 (Cth). Available at: <https://www.legislation.gov.au/Series/C1953A00095. See also AUSTRALIAN PARLIAMENT. The pharmaceutical benefits scheme - an overview. Available at: <https:// www.aph.gov.au/About_Parliament/Parliamentary_Departments/Parliamentary_Library/Publications_ Archive/archive/pbs>. Accessed in: 29 Mar. 2019.
} 
to provide advice, developed in consultation with the Australian, State and Territory Health Ministers ${ }^{24}$.

(v) the provision of universal health insurance to allow free access to hospitals and subsidised access to general practitioners (Medicare) ${ }^{25}$ that will be discussed below.

The States' powers on health primarily relate to the running of public hospitals, the registration and discipline of health professionals, control of health care complaints systems, guardianship of children and adults, mental health law, disability services and public health law.

\section{Rights to healthcare}

There is a dearth of Australian legal authority for a right to healthcare. The Australian Constitution contains very few human rights and none relate to health ${ }^{26}$. There are no broad common law or constitutional rights to access health care in Australia. At the State and Territory levels there are only two Australian jurisdictions with Bills of human rights, namely, Victoria and the ACT and neither expressly recognises a right to health care ${ }^{27}$. The Federal, State and Territory governments have also enacted anti-discrimination laws but none of these specifically deal with access to healthcare.

Rights to access healthcare can only really be found in Medicare. Medicare is the universal system of health insurance mentioned above. It was enacted via the Health Insurance Act 1973 (Cth) that provides a guarantee to all Australians that they can visit public hospitals for treatment and that the government will also pay for general practice visits, for up to $80 \%$ of a scheduled fee. Apart from these broad guarantees the system does not provide justiciable rights to patients, meaning that if the system fails to provide treatment there is no avenue for a patient to seek judicial review.

\footnotetext{
${ }^{24}$ National Health Reform Act 2011 (Cth). Available at: <https://www.legislation.gov.au/Series/C2011A00009>. Accessed in: 29 Mar. 2019. See also AUSTRALIAN COMMISSION ON SAFETY AND QUALITY IN HEALTHCARE. Governance. Available at: <https://www.safetyandquality.gov.au/about-us/governance/>. Accessed in: 10 Nov. 2018.

${ }^{25} \mathrm{Health}$ Insurance Act 1973. See also MEDICARE. About us. Available at: <https://www.humanservices. gov.au/organisations/about-us>. Accessed in: 10 Nov. 2018. Australia is also in the middle of rolling out a National Disability Insurance Scheme (NDIS) which is tasked with providing financial support to people with a disability: NATIONAL DISABILITY INSURANCE SCHEME. About us. Available at: <https://www.ndis.gov.au/ about-us.html>. Accessed in: 10 Nov. 2018.

${ }^{26}$ For example, the Constitution recognises freedom of religion, free of movement, right to trial by jury: ss 116 , 92, 120. There is also an implied right to freedom of political communication: Nationwide News Pty Ltd $v$ Wills (1992) 177 CLR 1.

${ }^{27}$ Human Rights Act 2004 (ACT). Available at: <https://www.legislation.act.gov.au/a/2004-5>. Accessed in: 29 March 2019; Charter of Human Rights and Responsibilities Act 2006 (Vic). Available at: <http://www5. austlii.edu.au/au/legis/vic/consol_act/cohrara2006433/>. Accessed in: 29 Mar. 2019.
} 
In addition to Medicare, the Commission has created an Australian Charter of Healthcare Rights ${ }^{28}$, with three guiding principles:

(i) Everyone has the right to be able to access health care and this right is essential for the Charter to be meaningful.

(ii) The Australian government is committed to international agreements about human rights which recognise everyone's right to have the highest possible standard of physical and mental health.

(iii) Australia is a society made up of people with different cultures and ways of life, and the Charter acknowledges and respects these differences ${ }^{29}$.

The Charter recognises a number of rights (Box).

Box. The Australian Charter of Healthcare Rights

\begin{tabular}{|ll|}
\hline Rights & What this means \\
\hline Access: I have a right to health care. & $\begin{array}{l}\text { I can access services to address my healthcare } \\
\text { needs. }\end{array}$ \\
Safety: I have a right to receive safe and high & I receive safe and high quality health services, \\
quality care. & $\begin{array}{l}\text { provided with professional care, skill and } \\
\text { competence. }\end{array}$ \\
Respect: I have a right to be shown respect, & The care provided shows respect to me and \\
dignity and consideration. & my culture, beliefs, values and personal \\
& characteristics. \\
Communication: I have a right to be informed & I receive open, timely and appropriate \\
about services, treatment, options and costs in & communication about my health care in a way I \\
c clear and open way. & can understand. \\
Participation: I have a right to be included in & I may join in making decisions and choices \\
decisions and choices about my care. & $\begin{array}{l}\text { about my care and about health service } \\
\text { planning. }\end{array}$ \\
Privacy: I have a right to privacy and & My personal privacy is maintained and proper \\
confidentiality of my personal information. & handling of my personal health and other \\
& information is assured. \\
Comment: I have a right to comment on my care & I can comment on or complain about my care \\
and to have my concerns addressed. & $\begin{array}{l}\text { and have my concerns dealt with properly and } \\
\text { promptly. }\end{array}$ \\
&
\end{tabular}

\footnotetext{
${ }^{28}$ There has been a recent review of the Charter but no results have been made available at the time of writing. See AUSTRALIAN COMMISSION ON SAFETY AND QUALITY IN HEALTHCARE. Australian Charter of healthcare rights. Available at: <https://www.safetyandquality.gov.au/national-priorities/charter-ofhealthcare-rights/>. Accessed in: 10 Nov. 2018.

${ }^{29}$ Id. Ibid.
} 
Importantly, the Charter is not based in legislation, and as such it appears that it is not intended to confer any legally enforceable rights to healthcare. These rights have never been the subject of litigation in Australia and it is unlikely that they are justiciable ${ }^{30}$. However, it may be possible to argue that the Charter form part of the contract for service with a health service provider or as creating a policy backdrop for understanding the provision of services.

For example, in Hospital and Health Boards Regulation 2012 (Cth) ${ }^{31}$, hospital services must have a consumer and community engagement strategy which has "regard to national and State strategies, policies, agreements and standards relevant to promoting consultation with health consumers and members of the community about the provision of health services by the Service." The Australian Charter and the Queensland Charter are given as examples of such national standards. In Queensland, the Health Ombudsman Regulation $2014^{32}$ prescribes the Charter as an enforceable 'conduct' document ${ }^{33}$; safety and quality committees must also take into account national standards such as the Charters. Another example comes from New South Wales which has a Policy Directive PD2011_022 Your Health Rights and Responsibilities 2011. This directive incorporates the Australian Charter and mandates that "All health professionals delivering healthcare services within NSW Health must be made aware of the detailed rights and responsibilities outlined in this publication" ${ }^{34}$.

\section{The Australian Health Practitioner Regulation National Law}

As stated above, registration and discipline of healthcare professionals has traditionally been a State and Territory matter and the Federal government has no express power to regulate the health professions. Any attempts to create an Australia-wide system of registration and discipline would only be possible if all the States and Territories worked together. On 26 March 2008 the Council of Australian Governments (COAG), a body made up of the relevant Federal, State and Territory Ministers, agreed to create a single national registration, complaints and discipline system known as the National Registration and Accreditation Scheme for the Health Professions. This system was enacted via the passage of legislation in Queensland, which, it was hoped, would then be enacted in the

\footnotetext{
${ }^{30}$ AUSTRALIAN COMMISSION ON SAFETY AND QUALITY IN HEALTHCARE. Using the Australian Charter of healthcare rights. Available at: <https://www.safetyandquality.gov.au/wp-content/ uploads/2014/07/Using-the-Charter-of-Healthcare-Rights-in-Your-Health-Service-v3.pdf>. Accessed in: 10 Nov. 2018.

${ }^{31}$ Hospital and Health Boards Regulation 2012 (Cth), r 13(1)(b).

${ }^{32}$ Health Ombudsman Regulation 2014, ss 5. Available at:<https://www.legislation.qld.gov.au/view/ pdf/2014-07-01/sl-2014-0124>. Accessed in: 29 Mar. 2019.

${ }^{33}$ Health Ombudsman Regulation 2014, r 32(a)(iv), cit.

${ }^{34}$ PD2011_022 Your Health Rights and Responsibilities 2011.
} 
same form in the other Australian jurisdictions ${ }^{35}$. However, immediately New South Wales decided to adopt a different system for complaints handing and discipline, described as a 'co-regulatory system', which will be discussed further below. In 2013, Queensland also decided to adopt a co-regulatory system for complaints and discipline.

The main purpose behind the new regime is stated in the National Law at section 3:

(a) to provide for the protection of the public by ensuring that only health practitioners who are suitably trained and qualified to practise in a competent and ethical manner are registered; and

(b) to facilitate workforce mobility across Australia by reducing the administrative burden for health practitioners wishing to move between participating jurisdictions or to practise in more than one participating jurisdiction; and

(c) to facilitate the provision of high quality education and training of health practitioners; and

(d) to facilitate the rigorous and responsive assessment of overseas-trained health practitioners; and

(e) to facilitate access to services provided by health practitioners in accordance with the public interest; and

(f) to enable the continuous development of a flexible, responsive and sustainable Australian health workforce and to enable innovation in the education of, and service delivery by, health practitioners.

In New South Wales, the National Law, in addition to listing the above aims, also requires that "the protection of the health and safety of the public must be the paramount consideration." ${ }^{36}$ The section also outlines guiding principles for the National Law, namely:

(a) the scheme is to operate in a transparent, accountable, efficient, effective and fair way;

(b) fees required to be paid under the scheme are to be reasonable having regard to the efficient and effective operation of the scheme;

\footnotetext{
${ }^{35}$ Health Practitioner Regulation National Law (QId) 2009; Health Practitioner Regulation National Law (NSW) No 86a 2009; Health Practitioner Regulation National Law (Victoria) Act 2009 (Vic); Health Practitioner Regulation National Law (ACT) Act 2010 (ACT); Health Practitioner Regulation (National Uniform Legislation) Act 2010 (NT); Health Practitioner Regulation National Law (Tasmania) Act 2010 (Tas); Health Practitioner Regulation National Law (South Australia) Act 2010 (SA); Health Practitioner Regulation National Law (WA) Act 2010 (WA).

${ }^{36}$ National Law, s 3A.
} 
(c) restrictions on the practice of a health profession are to be imposed under the scheme only if it is necessary to ensure health services are provided safely and are of an appropriate quality.

Nine health professions were originally included in the National Law but more have been added since, reaching a total of 15 registered professions. These registered professions include the following 'protected' titles set out in Table 1. Any health professional working under these protected titles must be registered under the National $\mathrm{Law}^{37}$.

Table 1. Registered Australian health professions and their protected titles ${ }^{38}$

\begin{tabular}{|c|c|}
\hline Profession & Protected title(s) \\
\hline $\begin{array}{l}\text { Aboriginal and Torres Strait Islander } \\
\text { Health Practice }\end{array}$ & $\begin{array}{l}\text { - } \quad \text { Aboriginal and Torres Strait Islander health } \\
\text { practitioner } \\
\text { - } \quad \text { Aboriginal health practitioner } \\
\text { - } \quad \text { Torres Strait Islander health practitioner }\end{array}$ \\
\hline Chinese Medicine & $\begin{array}{ll}\text { - } & \text { Chinese medicine practitioner } \\
\text { - } & \text { Chinese herbal dispenser } \\
\text { - } & \text { Chinese herbal medicine practitioner } \\
\text { - } & \text { Oriental medicine practitioner } \\
\text { - } & \text { Acupuncturist }\end{array}$ \\
\hline Chiropractic & - $\quad$ Chiropractor \\
\hline Dental & $\begin{array}{ll}\text { - } & \text { Dentist } \\
\text { - } & \text { Dental therapist } \\
\text { - } & \text { Dental hygienist } \\
\text { - } & \text { Dental prosthetist } \\
\text { Oral health therapist }\end{array}$ \\
\hline Medical & - $\quad$ Medical practitioner \\
\hline Medical Radiation Practice & $\begin{array}{ll}\text { - } & \text { Medical radiation practitioner } \\
\text { - } & \text { Diagnostic radiographer } \\
\text { - } & \text { Medical imaging technologist } \\
\text { - } & \text { Radiographer } \\
\text { - } & \text { Nuclear medicine scientist } \\
\text { - } & \text { Nuclear medicine technologist } \\
\text { - } & \text { Radiation therapist }\end{array}$ \\
\hline Nursing and Midwifery & $\begin{array}{ll}\text { - } & \text { Nurse } \\
\text { - } & \text { Registered nurse } \\
\text { - } & \text { Nurse practitioner } \\
\text { - } & \text { Enrolled nurse } \\
\text { - } & \text { Midwife } \\
\text { - } & \text { Midwife practitioner }\end{array}$ \\
\hline
\end{tabular}

\footnotetext{
${ }^{37}$ National Law, s 113. See WEIR, Michael. Holding out and protected titles - issues for non-registrant complementary and alternative health practitioners. Journal of law and Medicine, v. 25, n. 4, p. 10331041, Jul. 2018.

${ }^{38}$ Adapted from AHPRA. What we do. Available at: <https://www.ahpra.gov.au/About-AHPRA/What-We-Do/ FAQ.aspx>. Accessed in: 10 Nov. 2018.
} 
Continuation

\begin{tabular}{ll}
\hline Profession & Protected title(s) \\
\hline Occupational Therapy & - Occupational therapist \\
Optometry & - Optometrist \\
& Optician \\
Osteopathy & Osteopath \\
Paramedicine & Paramedic \\
Pharmacy & - Pharmacist \\
Physiotherapy & Pharmaceutical chemist \\
Podiatry & Physiotherapist \\
& - Physical therapist \\
Psychology & Podiatrist \\
\hline
\end{tabular}

\section{The Australian Health Practitioner Regulatory Agency and the structure of the National Law}

The National Law created a National Agency to implement and administer the law called the Australian Health Practitioner Regulatory Agency (AHPRA) which functions include:

- the establishment of procedures for the development of accreditation standards, registration standards and codes and guidelines approved by National Boards, for the purpose of ensuring the national registration and accreditation scheme operates in accordance with good regulatory practice;

- keeping an up-to-date and publicly accessible national register

- of registered health practitioners and students for each health profession;

- keeping an up-to-date and publicly accessible list of approved programs of study for each health profession;

- establishing an efficient procedure for receiving and dealing with notifications concerning health practitioners and students;

A current snapshot of AHPRA's activities can be seen below ${ }^{39}$ :

- 702,741 registered health practitioners in Australia, across 15 professions; over 23,800 (3.5\%) more registrants than 2016/2017;

- 73,759 new applications for registration received;

${ }^{39}$ AHPRA. Annual Report 2018. Available at: <https://www.ahpra.gov.au/annualreport/2018/notifications. html>. Accessed in: 10 Nov. 2018. 
- 161,114 students studying to be health practitioners through an approved program of study or clinical training program;

- $99 \%$ of registrants renewed and completed their registration online;

- 3,401 applications for registration refused because they did not meet suitability/ eligibility requirements (4.6\% of all new applications).

As part of its functions, AHPRA oversees 15 National Boards, one for each health profession. Each National Board has the primary role of protecting the public. The Boards are responsible for accreditation, registration of practitioners and students, creating professional standards, codes and scopes of practice and (except in New South Wales and Queensland) for dealing with complaints and discipline of members. This work is to be aided and supported by AHPRA ${ }^{40}$.

Each National Board also has a State and Territory Board (or 'Council' in New South Wales). These State and Territory-based Boards make individual registration and notification decisions, based on the National Board's policies and standards. State and Territory Boards usually delegate further responsibilities to specialist sub-committees, for example, registration committees, notifications assessment committees, health committees, and performance committees and professional standards committees. there are also committees that consider taking immediate action.

\section{Healthcare complaints and notifications under the National Law}

Prior to the introduction of the National Law, every State and Territory had an established system for making complaints about 'health services' to a commission, which had the power to receive, assess, investigate, review, refer and conciliate health services consumers' complaints ${ }^{41}$. These complaint's entities have continued to exist and have been incorporated into the National Law.

The definition of a 'health service' in these jurisdictions is generally very wide and includes services provided by registered practitioners and unregistered health providers. For example, in Health Care Complaints Act 1993 (NSW) s 3 a 'health service' is defined to include the practice of all the registered health professions outlined above, as well as other complementary and alternative health care practitioners who are not regulated under the National Law. Complaints can also be made against public and private service organisations ${ }^{42}$. Complaints may be made by any consumer of a health service (or by their representatives) and, in some

\footnotetext{
${ }^{40}$ National Law, s 35.

${ }^{41}$ Human Rights Commission Act 2005 (ACT); Health Care Complaints Act 1993 (NSW); Health and Community Services Complaints Act 1998 (NT); Health Quality and Complaints Commission Act 2006 (QId); Health and Community Services Complaints Act 2004 (SA); Health Complaints Act 1995 (Tas); Health Services (Conciliation and Review) Act 1987 (Vic); Health and Disability Services (Complaints) Act 1995 (WA).

${ }^{42}$ Health and Disability Services (Complaints) Act 1995 (WA).
} 
jurisdictions, like New South Wales, any person may make a complaint regarding a service even if they are not a patient/recipient of the health service ${ }^{43}$.

In all jurisdictions, the legislation allows for a complaint to be investigated, and provision is made to allow conciliation of health complaints by persons appointed as conciliators. The conciliation process is confidential and nothing revealed during the process can be used before a court or tribunal. Conciliators make reports on the outcome of the conciliation process; and if there has been no agreement between the parties the conciliator may make a recommendation that the complaint should be investigated or that the complaint should be referred to a Board (or Council) when the complaint relates to a registered health professional.

Complaints about registered health professionals are referred to as 'voluntary notifications' under the National Law ${ }^{44}$. Voluntary notifications can be made concerning the conduct, health or performance of a health care practitioner on the basis:

(a) that the practitioner's professional conduct is, or may be, of a lesser standard than that which might reasonably be expected of the practitioner by the public or the practitioner's professional peers;

(b) that the knowledge, skill or judgment possessed, or care exercised by, the practitioner in the practice of the practitioner's health profession is, or may be, below the standard reasonably expected;

(c) that the practitioner is not, or may not be, a suitable person to hold registration in the health profession, including, for example, that the practitioner is not a fit and proper person to be registered in the profession;

(d) that the practitioner has, or may have, an impairment;

(e) that the practitioner has, or may have, contravened this Law;

(f) that the practitioner has, or may have, contravened a condition of the practitioner's registration or an undertaking given by the practitioner to a National Board;

(g) that the practitioner's registration was, or may have been, improperly obtained because the practitioner or someone else gave the National Board information or a document that was false or misleading in a material particular ${ }^{45}$.

Voluntary notifications can also be made against students on the basis that:

\footnotetext{
${ }^{43}$ See Australian Vaccination Network Inc v Health Care Complaints Commission [2012] NSWSC 11 which lead to changes in the legislation in New South Wales.

${ }^{44}$ National Law, s 144.

${ }^{45} \mathrm{Ib}$. Ibid.
} 
(a) the student has been charged with an offence, or has been convicted or found guilty of an offence, that is punishable by 12 months imprisonment or more; or

(b) the student has, or may have, an impairment; or

(c) that the student has, or may have, contravened a condition of the student's registration or an undertaking given by the student to a National Board.

In New South Wales, the grounds for a voluntary notification are different from the other systems. Under s 144 of the New South Wales Act, a notification can be made when:

(a) A complaint the practitioner has, either in this jurisdiction or elsewhere, been convicted of or made the subject of a criminal finding for an offence.

(b) A complaint the practitioner has been guilty of unsatisfactory professional conduct or professional misconduct.

(c) A complaint the practitioner is not competent to practise the practitioner's profession.

(d) A complaint the practitioner has an impairment.

(e) A complaint the practitioner is otherwise not a suitable person to hold registration in the practitioner's profession.

\subsection{Self notification}

Practitioners are required to notify their relevant National Board within seven days of:

(i) the practitioner is charged, whether in a participating jurisdiction or elsewhere, with an offence punishable by 12 months imprisonment or more; or

(ii) the practitioner is convicted of or the subject of a finding of guilt for an offence, whether in a participating jurisdiction or elsewhere, punishable by imprisonment; or

(iii) appropriate professional indemnity insurance arrangements are no longer in place in relation to the practitioner's practice of the profession; or

(iv) the practitioner's right to practise at a hospital or another facility at which health services are provided is withdrawn or restricted because of the practitioner's conduct, professional performance or health; or

(v) the practitioner's billing privileges are withdrawn or restricted under the Medicare Australia Act 1973 of the Commonwealth because of the practitioner's conduct, professional performance or health; or

(vi) the practitioner's authority under a law of a State or Territory to administer, obtain, possess, prescribe, sell, supply or use a 
scheduled medicine or class of scheduled medicines is cancelled or restricted; or

(vii) a complaint is made about the practitioner to an entity referred to in section 219(1)(a) to (e) [which are Commonwealth authorities having functions relating to the provision of health services]; or

(viii) the practitioner's registration under the law of another country that provides for the registration of health practitioners is suspended or cancelled or made subject to a condition or another restriction $[\ldots]^{46}$

Students must also report themselves when:

(i) the student is charged with an offence punishable by 12 months imprisonment or more; or

(ii) the student is convicted of or the subject of a finding of guilt for an offence punishable by imprisonment; or

(iii) the student's registration under the law of another country that provides for the registration of students has been suspended or cancelled.

An example of the failure to self-report is Health Care Complaints Commission $v$ Haasbroek ${ }^{47}$. In this case a doctor was found guilty of professional misconduct for failing to notify the Medical Council of his conviction of assault occasioning actual bodily harm.

\subsection{Mandatory notifications}

Healthcare professionals also have mandatory notification obligations under the National $\mathrm{Law}^{48}$. Health practitioners are required to report any 'notifiable conduct' of other registered health practitioners and any behaviour by students, which may place the public at 'substantial risk of harm'49. 'Notifiable conduct' is conduct by a practitioner where the practitioner has:

(a) practised the practitioner's profession while intoxicated by alcohol or drugs; or

(b) engaged in sexual misconduct in connection with the practice of the practitioner's profession; or

(c) placed the public at risk of substantial harm in the practitioner's practice of the profession because the practitioner has an impairment; or

\footnotetext{
${ }^{46}$ National Law s 130.

${ }^{47}$ [2018] NSWCATOD 177. Similar cases include Dental Board of Australia and Dhillon [2018] WASAT 107; Medical Board of Australia v Hung Phan (Review and Regulation) [2018] VCAT 1324; HCCC v Grentell [2010] NSWNMT 27.

${ }^{48}$ National Law, s 141.

${ }^{49}$ MEDICAL BOARD OF AUSTRALIA. Guidelines for mandatory notifications. Available at: < https://www.medicalboard. gov.au/Codes-Guidelines-Policies/Guidelines-for-mandatory-notifications.aspx>. Accessed in: 10 Nov. 2018.
} 
(d) placed the public at risk of harm because the practitioner has practised the profession in a way that constitutes a significant departure from accepted professional standards ${ }^{50}$.

Exemptions exist for practitioners who are working for a professional indemnity insurer or as legal professionals, for members of quality assurance committees or for practitioners who might be prevented from disclosure due to some other legal prohibition ${ }^{51}$.

In 2017/ 2018 AHPRA received 908 mandatory notifications ${ }^{52}$. This was a rise of $7.2 \%$ compared to the previous. The overwhelming majority of notifications (79\%) concern medical practitioners or nurses. Nearly half of the notifications (45\%) resulted in some action being taken against the practitioner.

The mandatory notification provisions have caused considerable controversy and it has been argued that the requirement for mandatory notification is inappropriate for treating healthcare practitioners, as the requirement will discourage practitioners with health problems from seeking help, with the result that the public will face greater risk ${ }^{53}$. Western Australia has modified the notification requirement so that healthcare practitioners are exempted from reporting on health practitioner and students that they are providing health services to ${ }^{54}$. Queensland adopted a different variation, which does not require the health practitioner to notify the authorities regarding another practitioner seeking treatment when the behaviour relates to "an impairment, which will not place the public at substantial risk of harm" which is not professional misconduct ${ }^{55}$.

At present, AHPRA is considering a uniform change to the National Law, which would provide an exemption for treating health professionals all across Austra$\mathrm{lia}^{56}$. Four options have been raised which are outlined in diagram below. Of the four, only three are currently legalised, with Option 3 being left out. Option 1 represents the law as it currently is in all jurisdictions apart from Queensland and Western Australia. Option 2 represents the law in Western Australia. Option 4 is closest to the Queensland

\footnotetext{
${ }^{50}$ National Law, s 140.

${ }^{51}$ National Law, s 141.

${ }^{52}$ AHPRA. Annual Report 2018, cit.

${ }^{53}$ KOMESAROFF, Paul. Mandatory reporting of impaired doctors: protecting the community or increasing the risk? Internal Medicine Journal, Sydney, v. 44, n. 12a, p.1154-1155, Dec. 2014. https://doi.org/10.1111/ imj.12617; BISMARK, M.M.; MORRIS, J.M.; CLARKE, C. Mandatory reporting of impaired medical practitioners: protecting patients, supporting practitioners. Internal Medicine Journal, Sydney, v. 44, n. 12a, p.1165-1169, Dec. 2014; GOIRAN, Nick, KAY, Margaret, NASH, Louise; HAYSOM, Georgie. Mandatory reporting of health professionals: The case for a Western Australian style exemption for all Australian practitioners. Journal of Law and Medicine, Melbourne, v. 22, n. 1, p. 209, Sept. 2014.

${ }^{54}$ National Law (WA) Act 2010 (WA), s 141(4)(da).

${ }^{55}$ National Law (Queensland), s 144(5).

${ }^{56}$ AHPRA. Mandatory reporting under the Health Practitioner Regulation National Law 2017. Available at: <https://www.health.nsw.gov.au/legislation/Documents/dp-mandatory-reporting-hprnl.pdf >. Accessed in: 10 Nov. 2018.
} 
position. At the time of writing the Council of Australian governments has agreed to reform the law but they have not yet announced what option will be adopted ${ }^{57}$.

Diagram. AHPRA's mandatory reporting reform options ${ }^{58}$

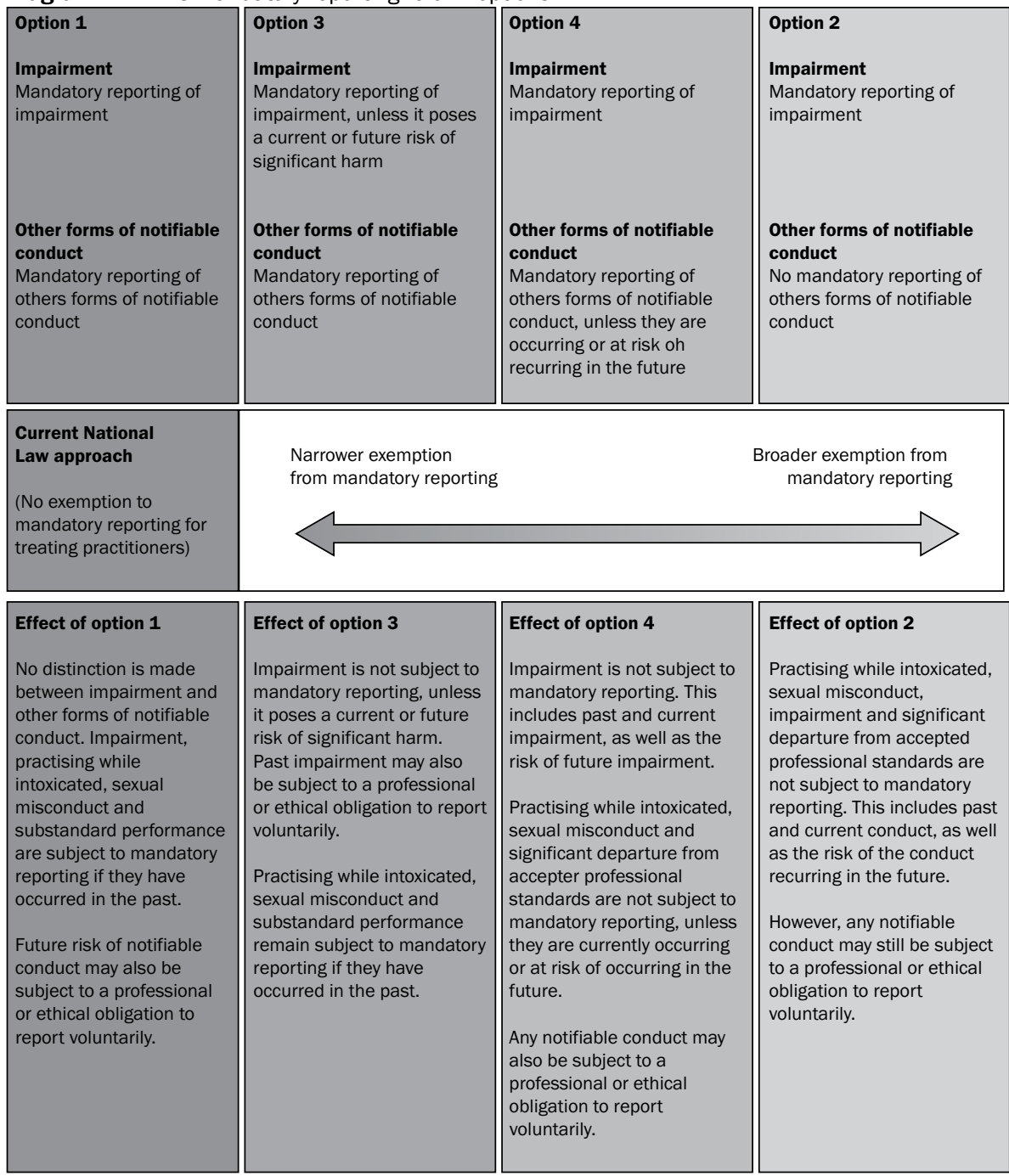

${ }^{57}$ AHPRA. Mandatory reporting under the Health Practitioner Regulation National Law 2017, cit.

${ }^{58}$ Id. Ibid. 


\section{Processing complaints and notifications}

Complaints can be lodged with AHPRA, a National Board, a State or Territory Board (or Council) or with a health care complaints entity. Under s 150 of the National Law the National Boards are required to inform health care complaints bodies about any notifications received by AHPRA, which may also provide grounds for a complaint. Conversely, if a complaint has been lodged with a healthcare complaints entity about a practitioner, the entity must notify the relevant National Board and give it the information that it has relating to the complaint (except for New South Wales and Queensland, which will be discussed below).

In all jurisdictions (apart from New South Wales and Queensland) AHPRA is obliged to refer a notification to the relevant National Board as soon as practicable after receiving it ${ }^{59}$. The National Board then has 60 days to conduct a preliminary assessment of the notification: National Law, s 149. After that assessment the National Board may:

- take immediate action on the practitioner's or student's registration;

- investigate the notification;

- request a health assessment of the practitioner or student or a performance assessment of the practitioner;

- refer the matter to a health or performance panel hearing;

- refer the matter to a tribunal hearing;

- issue a caution;

- accept undertakings;

- impose conditions; and/or

- take no further action.

If during assessment and investigation of a notification, a National Board may make a decision to place the investigation on hold pending other findings such as coronial investigations or criminal charges.

Below are the 2017/ 2018 statistics for AHPRA's notification activity ${ }^{60}$ :

- 10,934 practitioners had a notification raised about them nationally, this is an increase of 3.7\% from 2016/2017;

- $1.6 \%$ of all registered health practitioners were the subject of a notification;

\footnotetext{
${ }^{59}$ National Law, s 148.

${ }^{60}$ AHPRA. Annual Report 2018, cit.
} 
- the top three reasons for a notification were: clinical care (41.0\%); medication-related issues (12.6\%); and health impairment (8.9\%);

- immediate action was taken to restrict or suspend the registration of a practitioner 413 times;

- 7,276 notifications about practitioners were received; 5.5\% increase in notifications received;

- $24.5 \%$ of health, performance and conduct matters resulted in regulatory action;

- $97.0 \%$ of matters decided nationally by tribunals this year resulted in regulatory action;

- $7.2 \%$ increase in mandatory notifications received by AHPRA.

A complete breakdown by jurisdiction of the number of complaints can be seen in Table 2 .

\section{Immediate Action}

As discussed above, a National Board may decide after its initial assessment of a notification, or after an investigation, to initiate immediate action via an Immediate Action Committee. In 2017/18, National Boards took immediate action on 413 occasions, which is $29.4 \%$ (320) more than in 2016/2017 . The proportion of notifications where immediate action was taken was $5.7 \%$ of the notifications received. This is relatively consistent with previous years (4.6\% in 2016/ 2017 and $6.2 \%$ in $2015 / 2016)^{62}$.

Section 156 of the National Law provides that a Board can take immediate action against a practitioner if:

(a) the National Board reasonably believes that

(i) because of the registered health practitioner's conduct, performance or health, the practitioner poses a serious risk to persons; and

(ii) it is necessary to take immediate action to protect public health or safety; or

(b) the National Board reasonably believes that

(i) the student poses a serious risk to persons because the student-

(A) has been charged with an offence, or has been convicted or found guilty of an offence, that is punishable by 12 months imprisonment or more; or

${ }^{61}$ AHPRA. Annual Report 2018, cit.

${ }^{62}$ Id. Ibid. 
(B) has, or may have, an impairment; or

(C) has, or may have, contravened a condition of the student's registration or an undertaking given by the student to a National Board; and

(ii) it is necessary to take immediate action to protect public health or safety; or

(c) the registered health practitioner's registration was improperly obtained because the practitioner or someone else gave the National Board information or a document that was false or misleading in a material particular; or

(d) the registered health practitioner's or student's registration has been cancelled or suspended under the law of a jurisdiction, whether in Australia or elsewhere, that is not a participating jurisdiction.

(e) the National Board reasonably believes the action is otherwise in the public interest ${ }^{63}$.

Section 155 defines 'immediate action' to mean:

(a) the suspension, or imposition of a condition on, the health practitioner's or student's registration; or

(b) accepting an undertaking from the health practitioner or student; or

(c) accepting the surrender of the health practitioner's or student's registration

If a Board is proposing to take immediate action it must notify the practitioner and invite them to make a submission to the Board ${ }^{64}$. In Eaton v Dental Board of Australia the failure to afford a reasonable opportunity to a doctor to attend an immediate action meeting was said to be a breach of procedural fairness and the decision was overturned. ${ }^{65}$

The public interest criterion in s 156(e) was recently added to the National Law, after having been in place in New South Wales for 10 years. The criterion allows the Immediate Action Committee to suspend or place a condition on the practitioner for behaviours which may not be connected to the practitioner's professional behaviour but which still raises concerns about their ability to practice. For example, in Farshchi $v$ Chiropractic Board of Australia (Review and Regulation) ${ }^{66}$ a practitioner who was registered in three professions (medical practitioner, chiropractor and Chinese medicine practitioner) was charged with a number of very serious

\footnotetext{
${ }^{63}$ See also National Law (New South Wales), s 150.

${ }^{64}$ National Law, s 157.

${ }^{65}[2012]$ VSC 510.

${ }^{66}[2018]$ VCAT 1618.
} 
Bec C.S.

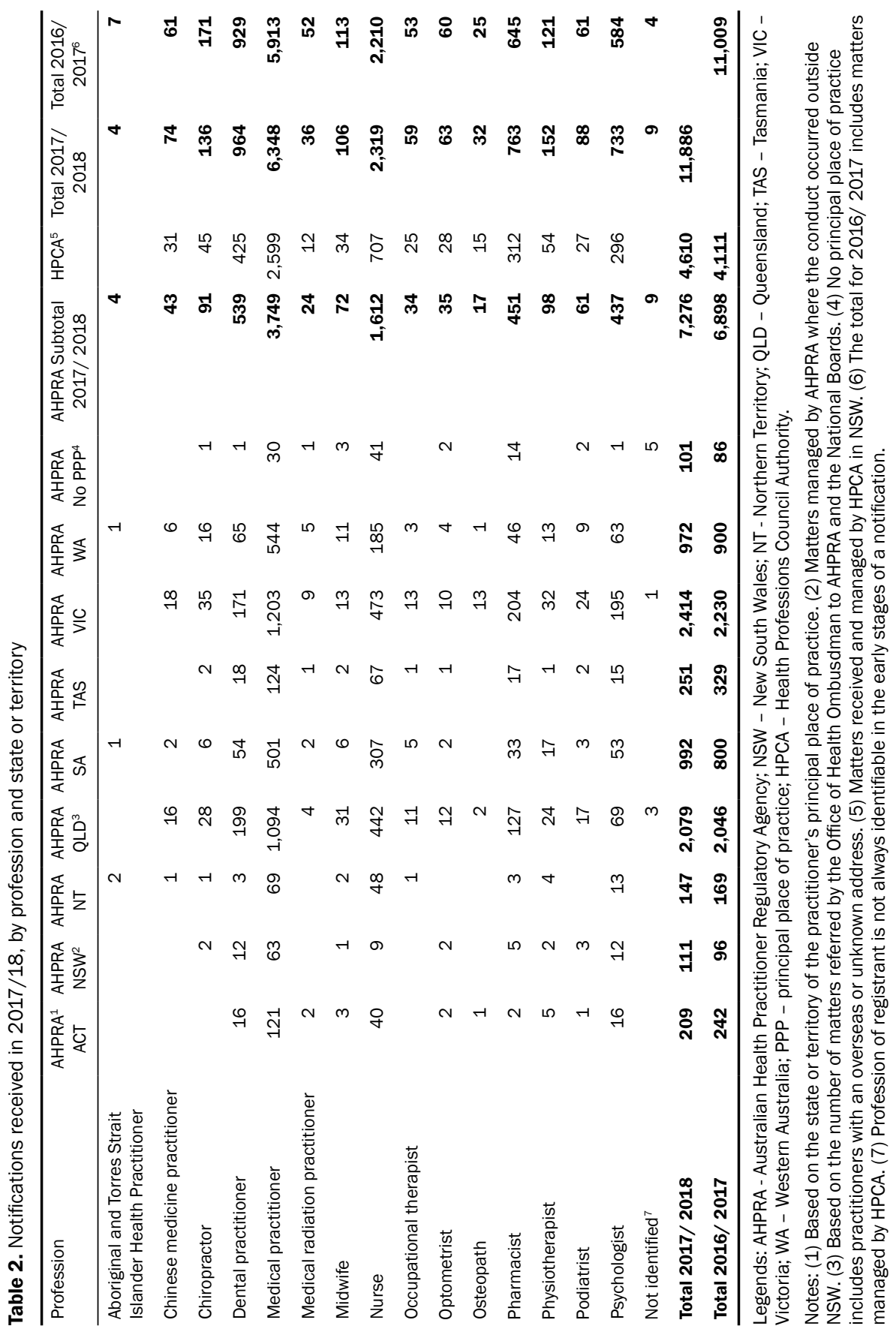


offences concerning forced labour (slavery). An Immediate Action Committee felt it necessary to impose high level supervision conditions on Dr Farshchi's practice. On appeal to the Victorian Civil and Administrative Tribunal, the Tribunal upheld the conditions in the public interest as the allegations concerned misuse of power on vulnerable people which may adversely affect the public's perception of the profession, even though it was unconnected with Dr Farshchi's practice.

\section{Adverse findings: Unsatisfactory professional performance, unsatisfactory professional conduct and professional misconduct}

The approach taken in the National Law in all jurisdictions (apart from New South Wales) has been to describe three forms of conduct which can lead to disciplinary sanction: unsatisfactory professional performance, unsatisfactory professional conduct, and professional misconduct. Section 3 of the National Law defines 'unsatisfactory professional performance' to mean that:

[...] the knowledge, skill or judgment possessed, or care exercised by, the practitioner in the practice of the health profession in which the practitioner is registered is below the standard reasonably expected of a health practitioner of an equivalent level of training or experience.

Section 3 of the National Law defines 'unprofessional conduct' to mean:

[...] professional conduct that is of a lesser standard than that which might reasonably be expected of the health practitioner by the public or the practitioner's professional peers, and includes--

(a) a contravention by the practitioner of this Law, whether or not the practitioner has been prosecuted for, or convicted of, an offence in relation to the contravention; and

(b) a contravention by the practitioner of

(i) a condition to which the practitioner's registration was subject; or

(ii) an undertaking given by the practitioner to the National Board that registers the practitioner; and

(c) the conviction of the practitioner for an offence under another Act, the nature of which may affect the practitioner's suitability to continue to practise the profession; and

(d) providing a person with health services of a kind that are excessive, unnecessary or otherwise not reasonably required for the person's well-being; and

(e) influencing, or attempting to influence, the conduct of another registered health practitioner in a way that may compromise patient care; and 
(f) accepting a benefit as inducement, consideration or reward for referring another person to a health service provider or recommending another person use or consult with a health service provider; and

(g) offering or giving a person a benefit, consideration or reward in return for the person referring another person to the practitioner or recommending to another person that the person use a health service provided by the practitioner; and

(h) referring a person to, or recommending that a person use or consult, another health service provider, health service or health product if the practitioner has a pecuniary interest in giving that referral or recommendation, unless the practitioner discloses the nature of that interest to the person before or at the time of giving the referral or recommendation.

Finally, section 3 defines 'professional misconduct' to include:

(a) unprofessional conduct by the practitioner that amounts to conduct that is substantially below the standard reasonably expected of a registered health practitioner of an equivalent level of training or experience; and

(b) more than one instance of unprofessional conduct that, when considered together, amounts to conduct that is substantially below the standard reasonably expected of a registered health practitioner of an equivalent level of training or experience; and

(c) conduct of the practitioner, whether occurring in connection with the practice of the health practitioner's profession or not, that is inconsistent with the practitioner being a fit and proper person to hold registration in the profession.

As stated above, New South Wales has adopted different terms and definitions which are more specific than those contained in the other jurisdictions. These definitions were in use in New South Wales prior to the introduction of the National Law and the legislators believed they were more effective than the ones stated in the drafts of the National Law. ${ }^{67}$ Section 153 of the Health Practitioner Regulation National Law (NSW) Act 2009 (NSW) defines 'unsatisfactory' performance as performance "below the standard reasonably expected of a practitioner of an equivalent level of training or experience." Section 139B defines 'unsatisfactory professional conduct' to include specific examples, such as:

\section{(a) Conduct significantly below reasonable standard}

Conduct that demonstrates the knowledge, skill or judgment possessed, or care exercised, by the practitioner in the practice

\footnotetext{
${ }^{67}$ PARLIAMENT OF NEW SOUTH WALES. Hansard for the Health Practitioner Regulation Bill 2009 - - 1R 2R NSW Parliament Health Practitioner Regulation Bill - Ms CARMEL TEBBUTT (Marrickville-Deputy Premier, and Minister for Health) 28 October 2009.
} 
of the practitioner's profession is significantly below the standard reasonably expected of a practitioner of an equivalent level of training or experience.

(b) Contravention of this Law or regulations

A contravention by the practitioner (whether by act or omission) of a provision of this Law, or the regulations under this Law or under the NSW regulations, whether or not the practitioner has been prosecuted for or convicted of an offence in respect of the contravention.

(c) Contravention of conditions of registration or undertaking

A contravention by the practitioner (whether by act or omission) of-

(i) a condition to which the practitioner's registration is subject; or

(ii) an undertaking given to a National Board.

(d) Failure to comply with decision or order of Committee or Tribunal

A contravention by the practitioner (whether by act or omission) of a decision or order made by a Committee or Tribunal in relation to the practitioner.

(e) Contravention of requirement under Health Care Complaints Act 1993

A contravention by the practitioner of section $34 \mathrm{~A}(4)$ of the Health Care Complaints Act 1993.

(f) Accepting benefit for referral or recommendation to health service provider

Accepting from a health service provider (or from another person on behalf of the health service provider) a benefit as inducement, consideration or reward for-

(i) referring another person to the health service provider; or

(ii) recommending another person use any health service provided by the health service provider or consult with the health service provider in relation to a health matter.

(g) Accepting benefit for recommendation of health product

Accepting from a person who supplies a health product (or from another person on behalf of the supplier) a benefit as inducement, consideration or reward for recommending that another person use the health product, but does not include accepting a benefit that consists of ordinary retail conduct.

(h) Offering a benefit for a referral or recommendation

Offering or giving a person a benefit as inducement, consideration or reward for the person-

(i) referring another person to the registered health practitioner; or 
(ii) recommending to another person that the person use a health service provided by the practitioner or consult the practitioner in relation to a health matter.

(i) Failure to disclose pecuniary interest in giving referral or recommendation

Referring a person to, or recommending that a person use or consult-

(i) another health service provider; or

(ii) a health service; or

(iii) a health product;

if the practitioner has a pecuniary interest in giving that referral or recommendation, unless the practitioner discloses the nature of the interest to the person before or at the time of giving the referral or recommendation.

(j) Engaging in overservicing

Engaging in overservicing.

\section{(k) Supervision of assistants}

Permitting an assistant employed by the practitioner (in connection with the practitioner's professional practice) who is not a registered health practitioner to attend, treat or perform operations on patients in respect of matters requiring professional discretion or skill.

\section{(l) Other improper or unethical conduct}

Any other improper or unethical conduct relating to the practice or purported practice of the practitioner's profession. (Original highlights)

Finally, section 139E defines professional misconduct' to mean:

(a) unsatisfactory professional conduct of a sufficiently serious nature to justify suspension or cancellation of the practitioner's registration; or

(b) more than one instance of unsatisfactory professional conduct that, when the instances are considered together, amount to conduct of a sufficiently serious nature to justify suspension or cancellation of the practitioner's registration.

\section{6. 'Co-regulation' in New South Wales and Queensland}

The position in New South Wales and Queensland is different. Unlike all the other States and Territories, New South Wales and Queensland enacted a different version of the National Law which is referred to as 'a co-regulatory model.' Under the co-regulatory model, AHPRA must not deal with notifications and must refer 
all notifications to the Health Professions Council Authority or the Queensland Office of Health Ombudsman. These entities then work with the various professional Boards and Councils to discuss how to proceed with a complaint.

In New South Wales, all complaints are processed by the Health Professions Council Authority (HPCA). If the complaint is very serious it is sent to the relevant health professional Council for determination about which Immediate Action and interim orders can be made to protect the public's safety and the public interest. If there is no needed for immediate action (or if such action has been taken) the New South Wales Health Care Complaints Commission and the health professional Councils consult with each other about how to appropriately deal with the complaint. Less serious cases not requiring full investigation are dealt with by the relevant Council, who refers the complaint to a conduct committee, health committee or performance committee, who will then investigate and may make conditions on the professional's practice, or, in cases when it turns out to be more serious than originally thought, the matter can be referred back to the Health Care Complaints Commission. In cases of serious public health issues, significant issues regarding appropriate care or treatment, cases of possible gross negligence or grounds for disciplinary proceedings, the New South Wales Health Care Complaints Commission may investigate the complaint initially and may refer it to the Director of Proceedings, who then independently determines whether to prosecute the case and where. In New South Wales, complaints about unsatisfactory professional conduct are normally heard before a Professional Standards Committee; the Health Care Complaints Tribunal will prosecute more serious complaints about professional misconduct before the New South Wales Civil and Administrative Tribunal. Appeals can be made from that Tribunal to the New South Wales Supreme Court but only on the limited grounds that the Tribunal has made an error of law.

In Queensland, the process is very similar to that in New South Wales. The Office of the Health Ombudsman receives all complaints and then, usually within 30 days, determine whether to take no further action, attempt to facilitate local resolution, attempt to conciliation, refer the complaint to the relevant health professional board, take immediate action against the provider, or investigate the matter further for prosecution ${ }^{68}$.

\section{Disciplinary proceedings}

The National Law provides for a number of different fora for the consideration of issues of professional discipline including tribunals, performance committees, conduct committees and health committees. The primary purpose of these proceedings is the protection of the public, not the punishment of wrongdoing ${ }^{69}$.

\footnotetext{
${ }^{68}$ OFFICE OF THE HEALTH OMBUDSMAN. What happens when the OHO receives a complaint? Available at: <https://www.oho.qld.gov.au/health-service-providers/what-happens-when-the-oho-receives-a-complaint/>. Accessed in: 10 Nov. 2018.

${ }^{69}$ Lee v Health Care Complaints Commission [2012] NSWCA 30.
} 
Then most serious response to an adverse finding is removal from the register. However, this response is far less likely than a response to that requires supervision, further education, a reprimand, and suspension from practice for a period of time or a fine. Table 3 provides a breakdown of the results of notifications from AHPRA (but excluding NSW decisions).

The disciplinary tribunals and panels are not courts and are not subject to the same requirements of procedure and evidence as a common law court. The main requirement of the tribunals is that of procedural fairness, which requires the tribunal or panel to give the practitioner a fair opportunity to listen to the allegations and present their own evidence ${ }^{70}$. Proceedings normally consist of two stages - a hearing stage, and, if there are adverse findings, a stage to consider the appropriate course of disciplinary action ${ }^{71}$. In both stages the practitioner should be afforded a reasonable opportunity to be heard ${ }^{72}$.

\section{Impaired practitioners}

Impairment is defined in the National Law, s 3 to mean that:

[...] the person has a physical or mental impairment, disability, condition or disorder (including substance abuse or dependence) that detrimentally affects or is likely to detrimentally affect--

(a) for a registered health practitioner or an applicant for registration in a health profession, the person's capacity to practise the profession; or

(b) for a student, the student's capacity to undertake clinical training--

(i) as part of the approved program of study in which the student is enrolled; or

(ii) arranged by an education provider.

As shown by Table 3, about 9\% of AHPRA's 2017/2018 notifications are related to impairment. Decisions concerning impairment are not made publicly available and are not recorded on the national register. A person can make voluntary notifications regarding impairment; practitioners must also report impairments as notifiable conduct if there is a belief that the impairment exposes the public at substantial risk of harm. When health-related notifications are received by AHPRA, the practitioner or student will be subjected to a health assessment by the relevant National Board, usually via a Health Committee.

\footnotetext{
${ }^{70}$ King v Health Care Complaints Commission [2011] NSWCA 353.

${ }^{71}$ Sudath v Health Care Complaints Commission [2012] NSWCA 171.

${ }^{72}$ Lucire v Health Care Complaints Commission [2011] NSWCA 99; Attia v Health Care Complaints Commission [2017] NSWSC 1066.
} 
Health practitioner regulation in Australia

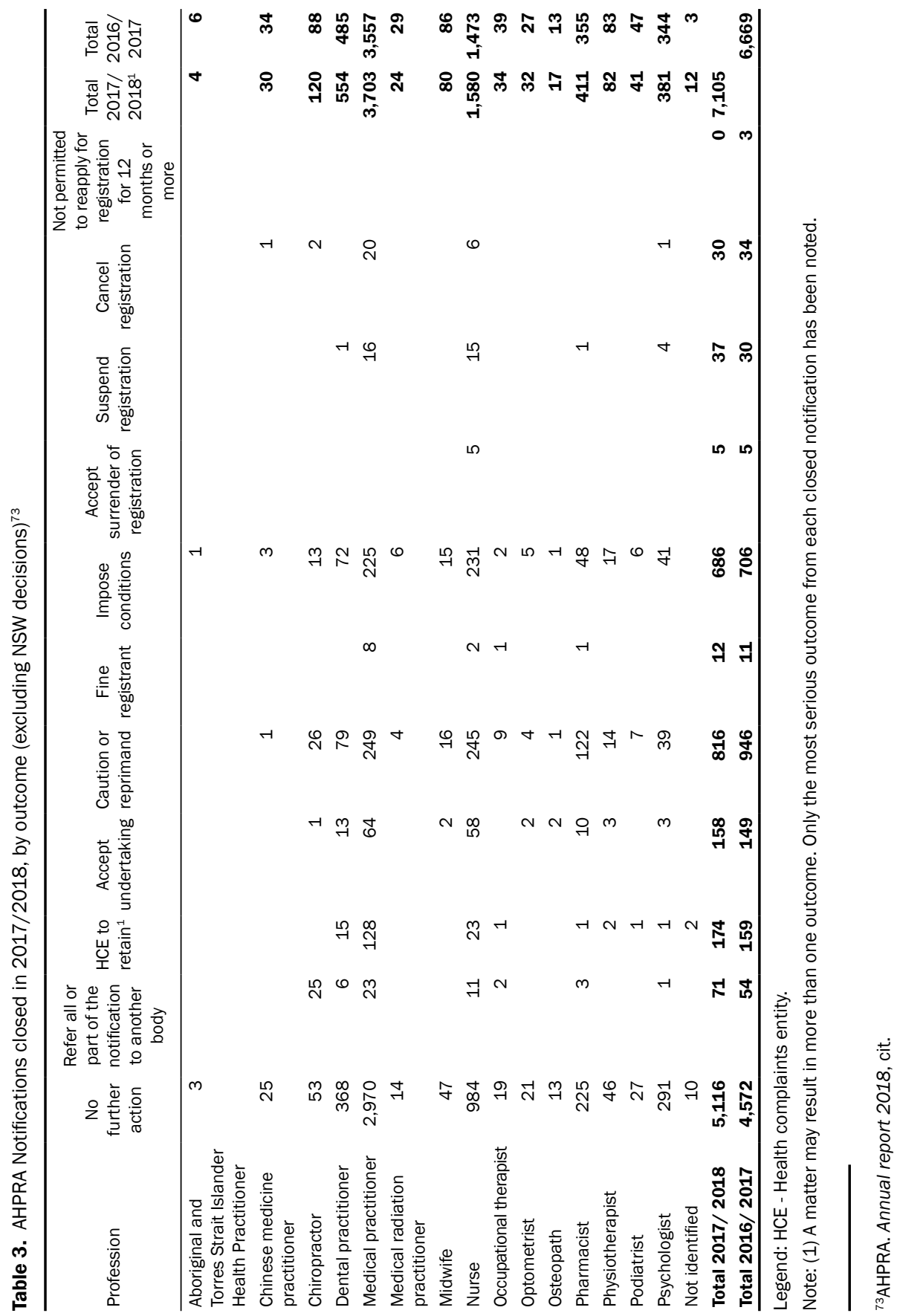


If an impairment has been found, a health committee can place conditions on the practitioners which limits their rights to practice (for example, for preventing them from prescribing drugs or addiction), require them to seek treatment (for example, psychiatric treatment, treatment for addiction) and to have them regularly drug tested ${ }^{74}$.

Findings of impairment can be contested ${ }^{75}$. A finding of impairment is not a defence to an allegation of unprofessional conduct or professional misconduct. In Reimers $v$ Health Care Complaints Commission a doctor had been deregistered for professional misconduct for matters arising from his narcotics addiction ${ }^{76}$. He argued that once it was decided that he had an impairment that he should had been dealt with by an impairment panel rather than by the Tribunal. The Court of Appeal disagreed. Judge Basten J. A. said at:

Gross, repeated, incompetent medical practice does not cease to be such because it is caused by an addiction to alcohol, heroin or other drugs. This was not a case where the practitioner was held to be unaware of his condition or its consequences. That he continued to practice as an anaesthetist whilst unable to exercise the necessary care, skill and judgment, could reasonably be found to constitute professional misconduct. The conclusion of the Tribunal that there was professional misconduct was, at least, unsurprising [...] There is no doubt that addiction is a condition which may, perhaps should, evoke sympathy. The degree to which a criminal offence is caused by a mental illness, including addiction, may properly be reflected in the sentence imposed. Nevertheless, "protection of the community" is a relevant sentencing principle and may, within limits of proportionality identified by reference to the seriousness of the offence, extend rather than restrict the sentence [...] But the underlying purpose of a disciplinary order of deregistration is not primarily punitive, but protective. That is not to impose some artificial dichotomy of punitive and protective orders [...] Rather, it is to recognise the primary object of the Medical Practice Act which was 'to protect the health and safety of the public by providing mechanisms designed to ensure that [...] medical practitioners are fit to practise medicine': $2 \mathrm{~A}(1)$. Misconduct which could be classified as professional misconduct may properly lead to deregistration.

\section{Unregistered practitioners}

So far all of the discussion has focused on registered health professions but many health practitioner groups remain unregistered, including naturopaths,

\footnotetext{
${ }^{74}$ See for example, the NEW SOUTH WALES MEDICAL COUNCIL. Participant procedure: drug screening. <www.mcnsw.org.au/sites/default/files/procedure_-_participant_procedure_-_drug_screening_-_6_ feb_2018_-_effective_from_4_june_2018.pdf>. Accessed in: 10 Nov. 2018.

${ }^{75} \mathrm{MLN} O$ v Medical Board of Australia (Occupational and Business Regulation) [2012] VCAT 1613.

${ }^{76}$ [2012] NSWCA 317. Reimers was later admitted back into practice with numerous conditions attached, such as restrictions on his rights to prescribe and requirements concerning supervision: Reimers $v$ Medical Council of New South Wales [2018] NSWCATOD 180.
} 
acupuncturists, psychotherapists, therapeutic masseurs, social workers, and homeopaths. This sector of the Australian economy is large and growing. For example, in 2017/ 2018 Australians spent nearly \$5 billion on complementary and alternative medicines $^{77}$.

While unregistered practitioners are not subject to the National Law in terms of having a National Board and other infrastructure, they are still subject to the protected titles laws (discussed above) and they are also regulated by the health care complaints systems in each jurisdiction. In 2015, COAG created a National Code of Conduct for Health Care Workers which was based on earlier codes created in New South Wales, South Australia and Queensland. It was created after a series of consultations and the final code was given to the health care complaints entity in each state to adopt through its own regulation. At present only New South Wales, Queensland, South Australia and Victoria have adopted a code ${ }^{78}$.

These codes are a form of 'negative licensing', meaning that it applies automatically to all unregistered persons providing health services. For example, in New South Wales unregistered practitioners are subject to the Code of Conduct for Unregistered Health Practitioners $^{79}$. Section 10AM of the Public Health Act 2010 (NSW), s 100 allows codes to be created to regulated unregistered practitioners and The Code applies 'negatively' in the sense that it does not need to be consented to by the practitioner. The Code deals with many matters such as:

- the provision of services in safe and ethical manner;

- ensuring infection control;

- the prohibition of practitioners claiming cures for cancer and other terminal illnesses;

- appropriate advice giving and not dissuading patients from seeking treatment from medical practitioners;

- not practicing under the influence of drugs an alcohol;

- not to practice with mental and physical impairments;

- not to financially exploit clients;

- requiring treatments to have a clinical basis;

\footnotetext{
${ }^{77}$ COMPLEMENTARY MEDICINES AUSTRALIA. Complementary medicine snapshot. <http://www. cmaustralia.org.au/resources/Documents/Australian\%20Complementary\%20Medicines\%20Industry\%20 snapshot\%202018_English.pdf>. Accessed in: 10 Nov. 2018.

${ }^{78}$ See National Code of Conduct for Health Care Workers (Queensland); Code of Conduct for Unregistered Health Practitioners (South Australia); General code of conduct in respect of general health services (Victoria). Tasmania has passed legislation to incorporate a Code but is not yet in force: Health Complaints Amendment (Code of Conduct) Act 2018. See also, WARDLE, Jon. Holding unregistered health practitioners to account: an analysis of current regulatory and legislative approaches. Journal of Law and Medicine, Melbourne, v. 22, n. 2, p. 350-375, 2014.

${ }^{79}$ NEW SOUTH WALES MINISTRY OF HEALTH. Unregistered practitioners. <https://www.health.nsw.gov.au/ phact/Documents/coc-unregistered-practitioners.pdf>. Accessed in: 10 Nov. 2018.
} 
- prohibiting misinformation and misleading conduct;

- prohibiting sexual and improper personal relationships;

- requiring compliance with privacy laws;

- requiring the keeping of records;

- requiring professional indemnity insurance;

- requiring the display of the Code at the place of business; and

- requiring that optical devices be sold in accordance to a prescription.

Under Health Care Complaints Act 1993 (NSW), s 41A the NSWHCCC can order an unregistered practitioner to act with conditions on their practice or may ban them from practising all together, if they breach the Code and pose a risk to the health or safety of members of the public ${ }^{80}$.

\section{Conclusions and future directions}

The National Law is a complicated, multigovernment regulatory system that relies heavily on the support of the registered health professions for legitimacy and day-to-day operations. While some segments of the health professional community have been highly critical of the National Law all the major reviews of the system have been largely supportive of the Law and most suggested reforms have been minor and procedural in nature ${ }^{81}$.

One problem with the current National Law is the system's reliance on notifications for action. This requires the system to be a reactive system, one that responds to problems that have already occurred, rather than a system which creates and environment where errors are prevented from happening.

Another problem is with repeat offending and the appropriateness of allowing practitioners to continue practising after years of transgressions. Minor infractions, even when they are repeated, do not seem to trigger the system's concern for the safety of the public as much as infractions that might result in serious injuries

\footnotetext{
${ }^{80}$ See for example, NEW SOUTH WALES HEALTH CARE COMPLAINTS COMMISSION. Public Statement and Statement of Decision in relation to Ms Marilyn Bodnar 23 July 2018. Available at: <http://www.hccc. nsw.gov.au/Hearings---decisions/Public-statements-and-warnings/Public-Statement-and-Statement-ofDecision-in-relation-to-Ms-Marilyn-Bodnar>. Accessed in: 10 Nov. 2018.

${ }^{81}$ See for example, AUSTRALIAN SENATE. Complaints mechanism administered under the Health Practitioner Regulation National Law 2017. Available at <https://www.aph.gov.au/Parliamentary_Business/ Committees/Senate/Community_Affairs/ComplaintsMechanism/Report>. Accessed in: 10 Nov. 2018. See also VICTORIAN PARLIAMENT Legislative Council Legal and Social Issues Legislation Committee. Inquiry into the Performance of the Australian Health Practitioner Regulation Agency 2014. Available at: <https:// www.parliament.vic.gov.au/images/stories/committees/SCLSI/Leg_ctee/AHPRA/Final_version_AHPRA_ report_30314.pdf>. Accessed in: 10 Nov. 2018.
} 
or death. Even when the results are serious, the system's concerns with re-education and re-training may disguise practitioners who are fundamentally unfit to practice ${ }^{82}$.

One possible approach to this problem would be to identify 'at risk' practitioners and seek them out for training or health interventions, before problems arise. This could involve some form of predictive modelling ${ }^{83}$. Alternatively (or additionally) it might also involve general schemes of revalidation, which require health professionals to be under regular testing for certain capacities and screened for potential problems ${ }^{84}$.

Overall, the National Law represents a successful attempt at a cross-governmental system of health workforce regulation. It has grown and strengthened in the last ten years, and it appears to have a degree of responsiveness that will allow it to adapt and change for the future.

\section{References}

AHPRA. Annual Report 2018. Available at: <https://www.ahpra.gov.au/annualreport/2018/ notifications.html>. Accessed in: 10 Nov. 2018.

. Mandatory reporting under the Health Practitioner Regulation National Law 2017. Available at: <https://www.health.nsw.gov.au/legislation/Documents/dp-mandatoryreporting-hprnl.pdf $>$. Accessed in: 10 Nov. 2018.

. What we do. Available at: <https://www.ahpra.gov.au/About-AHPRA/What-We-Do/ FAQ.aspx>. Accessed in: 10 Nov. 2018.

AUSTRALIAN BUREAU OF STATISTICS. Australian demographic statistics. Mar 2018. Available at: <http://www.abs.gov.au/AUSSTATS/abs@.nsf/mf/3101.0>. Accessed in: 10 Nov. 2018.

. Quick stats for Greater Sydney. Available at: <http://quickstats.censusdata.abs.gov. au/census_services/getproduct/census/2016/quickstat/1GSYD?opendocument>. Accessed in: 10 Nov. 2018.

\footnotetext{
${ }^{82}$ See for example, FURNESS, Gail. Review of processes undertaken by the Medical Council of New South Wales pursuant to Part 8 of the Health Practitioner Regulation National Law (NSW with respect to Dr Emil Gayed. 2018. Available at: <https://www.mcnsw.org.au/sites/default/files/furness_report-gayed.pdf>. Accessed in: 20 Nov. 2018.

${ }^{83}$ BISMARK, M.M.; SPITTAL, M.J; GURRIN, L.C; WARD, M; STUDDERT, D.M. Identification of doctors at risk of recurrent complaints: a national study of healthcare complaints in Australia. BMJ Quality and Safety, v. 22, n. 7, p. 532-540, 2013.

${ }^{84}$ CARTER, David; STREET, Deborah; BUSH, Stephen. Building public confidence in medical registration revalidation: reform of medical registration law in Australia, a New Risk-based Approach. Journal of Law and Medicine, v.25, n. 4, p.1009-1032, Jul. 2018.
} 
AUSTRALIAN COMMISSION ON SAFETY AND QUALITY IN HEALTHCARE. Australian Charter of healthcare rights. Available at: <https://www.safetyandquality.gov.au/nationalpriorities/charter-of-healthcare-rights/>. Accessed in: 10 Nov. 2018.

Governance. Available at: <https://www.safetyandquality.gov.au/about-us/ governance/>. Accessed in: 10 Nov. 2018.

Using the Australian Charter of healthcare rights. Available at: $<$ https://www. safetyandquality.gov.au/wp-content/uploads/2014/07/Using-the-Charter-of-HealthcareRights-in-Your-Health-Service-v3.pdf > . Accessed in: 10 Nov. 2018.

AUSTRALIAN PARLIAMENT. The pharmaceutical benefits scheme - an overview. Available at: $<$ https://www.aph.gov.au/About_Parliament/Parliamentary_Departments/Parliamentary_ Library/Publications_Archive/archive/pbs>. Accessed in: 10 Nov. 2018.

AUSTRALIAN SENATE. Complaints mechanism administered under the Health Practitioner Regulation National Law 2017. Available at <https:/www.aph.gov.au/Parliamentary_Business/ Committees/Senate/Community_Affairs/ComplaintsMechanism/Report $>$. Accessed in: 10 Nov. 2018.

AUSTRALIAN THERAPEUTIC GOODS ADMINISTRATION. Regulation basics. Available at: <https://www.tga.gov.au/regulation-basics >. Accessed in: 10 Nov. 2018.

BENNETT, Belinda, CARNEY, Terry, CHIARELLAI, Mary, WALTON, Merrilyn, KELLY, Patrick, SATCHELL Claudette, BEAUPERT, Fleur. Australia's national registration and accreditation scheme for health practitioners: a national approach to polycentric regulation? Sydney Law Review, v.40, n. 2, p. 140-181, 2018.

BISMARK, M.M.; MORRIS, J.M.; CLARKE, C. Mandatory reporting of impaired medical practitioners: protecting patients, supporting practitioners. Internal Medicine Journal, Sydney, v. 44, n. 12a, p.1165-1169, Dec. 2014.

.; SPITTAL, M.J; GURRIN, L.C; WARD, M; STUDDERT, D.M. Identification of doctors at risk of recurrent complaints: a national study of healthcare complaints in Australia. BMJ Quality and Safety, v. 22, n. 7, p. 532-540, 2013.

CARTER, David; STREET, Deborah; BUSH, Stephen. Building public confidence in medical registration revalidation: reform of medical registration law in Australia, a New Risk-based Approach. Journal of Law and Medicine, v.25, n. 4, p.1009-1032, Jul. 2018.

COMPLEMETARY MEDICINES AUSTRALIA. Complementary medicine snapshot. $<$ http://www.cmaustralia.org.au/resources/Documents/Australian\%20Complementary\%20 Medicines\%20Industry\%20snapshot\%202018_English.pdf>. Accessed in: 10 Nov. 2018.

CREYKE, Robyn; HAMER, David; O’MARA, Patrick; SMITH, Belinda; Taylor, T. Laying down the law. $10^{\text {th }}$ ed. Sydney: LexisNexis 2017. 
FURNESS, Gail. Review of processes undertaken by the Medical Council of New South Wales pursuant to Part 8 of the Health Practitioner Regulation National Law (NSW with respect to Dr Emil Gayed. 2018. Available at: <https://www.mcnsw.org.au/sites/default/files/furness_reportgayed.pdf>. Accessed in: 20 Nov. 2018.

GOIRAN, Nick, KAY, Margaret, NASH, Louise; HAYSOM, Georgie. Mandatory reporting of health professionals: The case for a Western Australian style exemption for all Australian practitioners. Journal of Law and Medicine, Melbourne, v. 22, n. 1, p. 209-220, Sept. 2014.

KERCHER, Bruce. R v Ballard, R v Murrell and R v Bonjon. Australian Indigenous Law Reporter v. 3, n 3, p. 410, 1998.

KOMESAROFF, Paul. Mandatory reporting of impaired doctors: protecting the community or increasing the risk? Internal Medicine Journal, Sydney, v. 44, n. 12a, p.1154-1155, Dec. 2014. https://doi.org/10.1111/imj.12617.

MEDICAL BOARD OF AUSTRALIA. Guidelines for mandatory notifications. Available at: $<$ https://www.medicalboard.gov.au/Codes-Guidelines-Policies/Guidelines-for-mandatorynotifications.aspx>. Accessed in: 10 Nov. 2018.

MEDICARE. About us. Available at: <https://www.humanservices.gov.au/organisations/ about-us>. Accessed in: 10 Nov. 2018.

NATIONAL DISABILITY INSURANCE SCHEME. About us. Available at: <https://www. ndis.gov.au/about-us.html>. Accessed in: 10 Nov. 2018.

NEW SOUTH WALES HEALTH CARE COMPLAINTS COMMISSION. Public Statement and Statement of Decision in relation to Ms Marilyn Bodnar 23 July 2018. Available at: <http://www. hccc.nsw.gov.au/Hearings---decisions/Public-statements-and-warnings/Public-Statementand-Statement-of-Decision-in-relation-to-Ms-Marilyn-Bodnar>. Accessed in: 10 Nov. 2018.

NEW SOUTH WALES MEDICAL COUNCIL. Participant procedure: drug screening. <www. mcnsw.org.au/sites/default/files/procedure_-_participant_procedure_-_drug_screening_-_6_ feb_2018_-_effective_from_4_june_2018.pdf>. Accessed in: 10 Nov. 2018.

NEW SOUTH WALES MINISTRY OF HEALTH. Unregistered practitioners. <https://www. health.nsw.gov.au/phact/Documents/coc-unregistered-practitioners.pdf $>$. Accessed in: 10 Nov. 2018.

OFFICE OF THE HEALTH OMBUDSMAN. What happens when the OHO receives a complaint? Available at: $<$ https://www.oho.qld.gov.au/health-service-providers/what-happenswhen-the-oho-receives-a-complaint/>. Accessed in: 10 Nov. 2018.

STEWART, Cameron, KERRIDGE, Ian, PARKER, Malcolm. The Australian medicolegal handbook. Sydney: Elsevier 2008. 
VICTORIAN PARLIAMENT Legislative Council Legal and Social Issues Legislation Committee. Inquiry into the Performance of the Australian Health Practitioner Regulation Agency 2014. Available at: <https://www.parliament.vic.gov.au/images/stories/committees/ SCLSI/Leg_ctee/AHPRA/Final_version_AHPRA_report_30314.pdf $>$. Accessed in: 10 Nov. 2018.

WARDLE, Jon. Holding unregistered health practitioners to account: an analysis of current regulatory and legislative approaches. Journal of Law and Medicine, Melbourne, v. 22, n. 2, p. $350-375,2014$.

WEIR, Michael. Holding out and protected titles - issues for non-registrant complementary and alternative health practitioners. Journal of law and Medicine, v. 25, n. 4, p. 1033-1041, Jul. 2018.

WILLIAMS, George, BRENNAN, Paul., LYNCH, Andrew. Australian constitutional law: commentary and materials. $7^{\text {th }}$ ed. Sydney: Federation Press, 2018.

Cameron Stewart Bec - Bachelor of Economics; Bachelor of Laws (First Class Honours); Graduate Diploma of Jurisprdence; Graduate Diploma of Legal Practice; Doctor of Philosophy. Professor of Health Law and Ethics, Sydney Law School, University of Sydney. Sydney, Australia. E-mail: cameron.stewart@sydney.edu.au 